\title{
Effect of Fertilizer, Organic Manure and Bio-fertilizer on Summer Grown Cowpea (Vigna unguiculata L. Walp)
}

\author{
Dhwani Bartwal and R. A. Patel* \\ Department of Agronomy B. A. College of AgricultureAnand \\ Agricultural University, Anand-388 110, Gujarat, India
}

In India, pulses are grown in an area of 25.21 million ha with a total production of 19.78 million tones with a productivity of $763 \mathrm{~kg} \mathrm{ha}^{-1}$. In Gujarat, it is cultivated in an area of 6.54 lakh ha with an annual production of 5.99 lakh tonnes and average productivity of $916 \mathrm{~kg} \mathrm{ha}^{-1}$ (Anonymous 2016). About a dozen of pulse crops viz., chickpea, pigeonpea, green gram, black gram, lentil, field pea, lathyrus, cowpea, common bean, moth bean, horse gram and rice bean are cultivated under varied agro-ecological conditions. Among the pulses, cowpea serves as a dual purpose food at both green shell and dry stage but its productivity is low owing to different reasons. In general pulses respond well to phosphorous application and seed inoculation with Rhizobium (Prasad and Sanoria 1984) but response could be larger if organic manure is supplemented. As such information for enhancing the productivity of cowpea is limited and hence the present investigation was carried out.

A field experiment was conducted at B.A College of Agriculture, Anand Agricultural University, Anand during summer 2018 with cowpea (var. GC4) as test crop. The experimental soil was loamy sand with low organic carbon and available nitrogen $(124.85 \mathrm{~kg}$ $\left.\mathrm{ha}^{-1}\right)$, medium available $\mathrm{P}_{2} \mathrm{O}_{5}\left(29.23 \mathrm{~kg} \mathrm{ha}^{-1}\right)$ and high available $\mathrm{K}_{2} \mathrm{O}\left(286.76 \mathrm{~kg} \mathrm{ha}^{-1}\right)$. There were 12 treatment namely, $\mathrm{T}_{1}$-no fertilizer (control); $\mathrm{T}_{2}$-RDF 20-40-00 kg $\mathrm{ha}^{-1}$ (NPK); $\mathrm{T}_{3}$-castor cake @ $0.5 \mathrm{t} \mathrm{ha}^{-1} ; \mathrm{T}_{4^{-}}$ vermicompost@1tha ${ }^{-1} ; \mathrm{T}_{5}$-FYM@4tha ${ }^{-1} ; \mathrm{T}_{6}$-castor cake@0.5 t ha-1 + PSB@ 5 ml kg ${ }^{-1}$ seed; $\mathrm{T}_{7}$ vermicompost@1 tha ${ }^{-1}+$ PSB@ 5 ml kg-1 seed; $\mathrm{T}_{8}$ FYM@4 tha ${ }^{-1}+$ PSB@5 ml kg seed; $^{-1}$-Rhizobium@

\footnotetext{
*Corresponding author: (Email: rajni@aau.in)
}

$5 \mathrm{ml} \mathrm{kg}{ }^{-1}$ seed + PSB @ $5 \mathrm{ml} \mathrm{kg}{ }^{-1}$ seed; $\mathrm{T}_{10}$ - castor cake

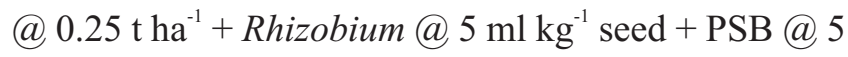
$\mathrm{ml} \mathrm{kg}{ }^{-1}$ seed; $\mathrm{T}_{11}$-vermicompost@ $0.5 \mathrm{tha}^{-1}+$ Rhizobium @ $5 \mathrm{ml} \mathrm{kg}^{-1}$ seed + PSB@ $5 \mathrm{ml} \mathrm{kg}^{-1}$ seed and T ${ }_{12}$ - FYM @ 2 tha ${ }^{-1}+$ Rhizobium@5 ml kg-1 seed+PSB@5 ml $\mathrm{kg}^{-1}$ seed in a Randomized Block Design with four replications. Chemical fertilizers were applied through urea and DAP but organic manures viz. castor cake and FYM were applied well in advance for proper decomposition whereas vermicompost was applied on the day of sowing. As per the seed rate $\left(25 \mathrm{~kg} \mathrm{ha}^{-1}\right)$, the required seed/plot $(3.60 \mathrm{~m} \times 5.0 \mathrm{~m})$ were inoculated with respective strains of Rhizobium (broth) and PSB (broth) and sown on $21^{\text {st }}$ February. Crop was harvested in second week of May. The cowpea raised under recommended agro-practices and the data generated during experiment was statistically analyzed (Panse and Sukhatme 1967).

Data (Table 1) indicated that different treatments had a significant influence on plant height, number of branches plant ${ }^{-1}$ and number of root nodules plant $^{-1}$. Application of RDF (20-40-00 kg NPK ha $\left.{ }^{-1}\right)$ recorded significantly higher plant height $(43.83 \mathrm{~cm})$ and higher number of branches per plant (6.10) being at par with treatment FYM $4 \mathrm{t} \mathrm{ha}^{-1}+$ PSB $5 \mathrm{ml} \mathrm{kg}$ seed, might be due to the availability of nutrients from chemical fertilizer and subsequent uptake of nutrients by the crop.

Among different treatments, significantly higher number of root nodule plant ${ }^{-1}$ (26.60) was recorded under the treatment FYM @ $2 \mathrm{tha}^{-1}+$

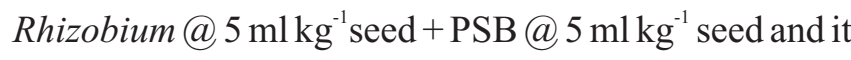
remained at par with treatment having vermicompost @ 


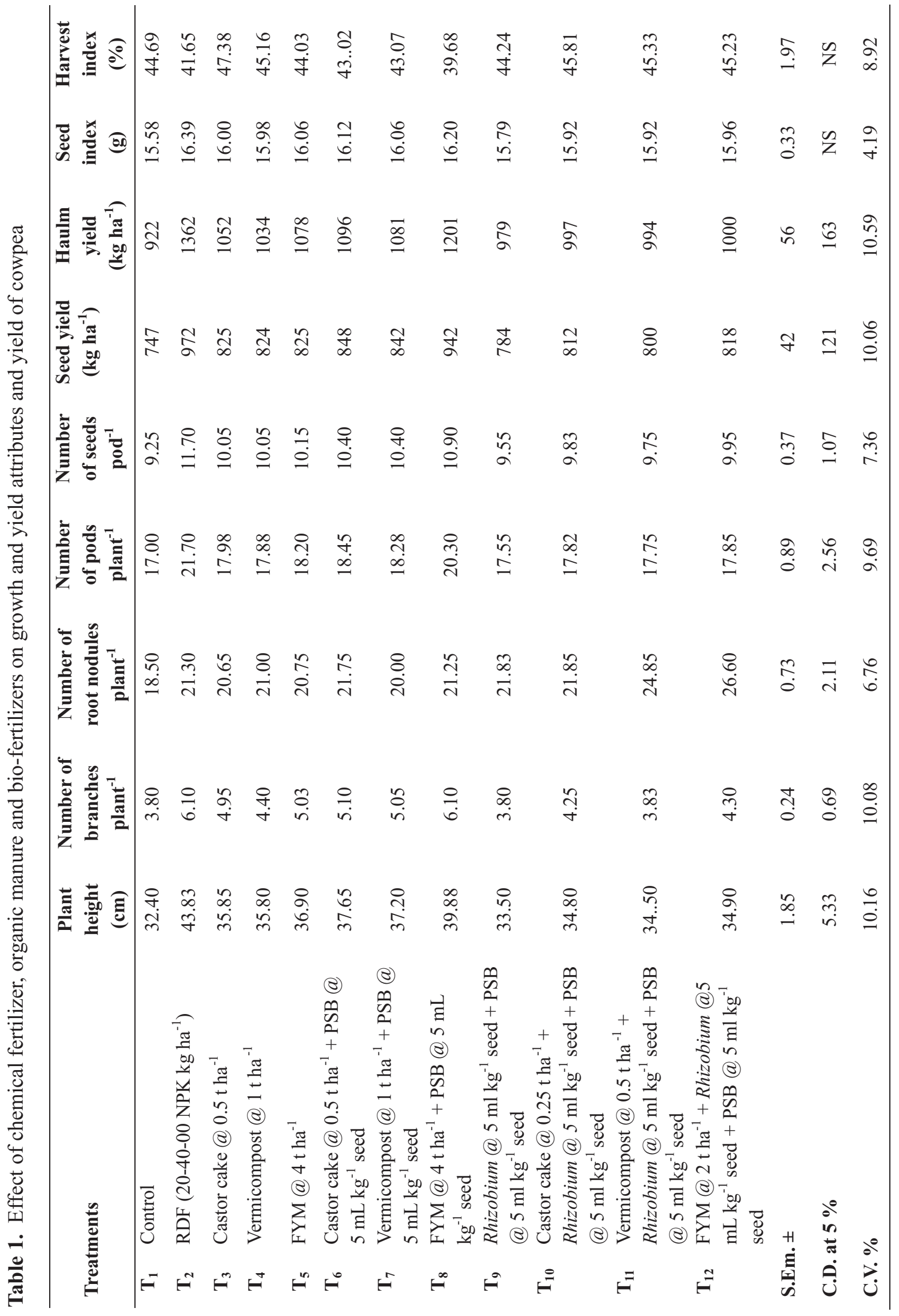


$0.5 \mathrm{tha}^{-1}+$ Rhizobium @ $5 \mathrm{ml} \mathrm{kg}^{-1}$ seed + PSB@ $9 \mathrm{ml} \mathrm{kg}^{-1}$ seed. Increase in root nodules might be ascribed to better availability of nutrients through FYM at critical growth stages. PSB might also have enhanced the availability of phosphorus to plants which must have been utilized in greater root development and nodulation. The results are in close agreement with the findings of Prasad et al. (1984), Hajare et al. (1994), Meena et al. (2015) and Pargi etal.(2018).

Application of RDF (20-40-00 NPK kg ha') recorded significantly higher number of pods plant ${ }^{-1}$, number of seeds pod $^{-1}$, higher seed and haulm yield which remained at par with treatment FYM@4 $4 \mathrm{tha}^{-1}+$ PSB@ $@ 5 \mathrm{ml} \mathrm{kg}^{-1}$ seed. More number of pods plant ${ }^{-1}$ might be due to more survival of flowers with high supply of photosynthates under treatment RDF as compared to other treatments. The higher number of seeds pod $^{-1}$ was obtained probably due to supplying of nutrients in the form of chemical fertilizer. The higher number of seed pod $^{-1}$ and haulm yields were also associated with recommended dose of fertilizer than other treatments. These results are in conformity with the results of Yadav and Malik (2005), Meena et al. (2015), Joshi et al. (2018), Pargi et al. (2018) and Singh etal.(2018).

\section{References}

Anonymous (2016). Prospects of Pulses-2016. Publication No.: DPD/Pub, 1(2).

Hajare, T. N., Jagdish Prasad and Naga Bhushana, S. R. (1994). Response of soybean (Glycine max) to phosphorus with and without nitrogen and Rhizobium inoculation in cracking clay soils. Indian Journal of Agricultural Sciences 64, 492-494.
Joshi, J. R., Patel, V. M., Barad, H. L., Macwan, S. M. and Javid, E. (2018). Effect of land configuration and fertilizer management practices on growth, yield and yield attributes and economics of summer cowpea (Vigna unguiculata L.) under south Gujarat condition. International Journal of Current Microbiology and Applied Science 7, 1148-1155.

Meena, J. S., Verma, H. P. and Pancholi, P. (2015). Effect of fertility levels and bio-fertilizers on the growth and yield of cowpea (Vigna unguiculata L. Walp) on sandy loam soil of Rajasthan. $A n$ Asian Journal of Soil Science 10, 55-58.

Panse, V. G. and Sukhatme, P. V. (1967). Statistical methods for agricultural workers, ICAR Pub. New Delhi, p, 361.

Jagdish Prasad and Sanoria, C. L. (1984). Associative effect of Rhizobium and Azotobacter at different levels of phosphorus on yields and nutrients content of bengal gram (Cicer arietinum). Legume Research 7, 13-16.

Pargi, K. L., Leva, R. L., Vaghasiya, H. Y. and Patel, H. A. (2018). Integrated nutrient management in summer cowpea (Vigna unguiculata L.) under south Gujarat conditions. International Journal of Current Microbiology and Applied Sciences 7, 1513-1522.

Singh, R., Singh, V., Singh, P. and Yadav, R. A. (2018). Effect of phosphorus and PSB on yield attributes, economics of summer greengram (Vigna radiata L.). Journal of Pharmacognosy and Phytochemistry 7, 404-408.

Yadav, R. D. and Malik, C. V. S. (2005). Effect of Rhizobium inoculation and various sources of nitrogen on growth and yield of cowpea (Vigna unguiculata L. Walp.). Legume Research 28, $38-41$.

Received: September, 2018 Accepted: December, 2018 